Scientific Journal Warsaw University of Life Sciences - SGGW

Problems of World Agriculture volume 18 (XXXIII), number 4, 2018: 92-101

DOI: 10.22630/PRS.2018.18.4.100

Tetiana Balanovska $^{1}$, Barbara Wyrzykowska ${ }^{2}$

${ }^{1}$ National University of Life and Environmental Sciences of Ukraine, Ukraine

${ }^{2}$ Warsaw University of Life Sciences - SGGW, Poland

\title{
The Requirements of the Contemporary Labour Market for Professionals
}

\begin{abstract}
The article substantiates that the contemporary labour market with its flexibility, volatility, high innovation dynamics, as its main features, introduces new requirements for employees. The study analyses the Ukrainian population's employment, in the rural areas, forestry and fishing, in particular. The study determines the problems of the insufficient level of satisfaction of the employers' need in employees. The research sums up different scientific approaches to the expectation that employers have to professional specialists. It establishes that employers' requirements for future employees differ regarding their professional experience. The article explains the findings of the research assisting specialists to focus on the core knowledge concerning the practical aspect. The article provides analysis that refers to the set of personal qualities and abilities acting as factors of managers' compliance with the demands of the contemporary labour market. The findings of the article single out the role and significance of logical thinking as a component of forming successful managers.
\end{abstract}

Keywords: labour market, population, employment, specialist, manager, competence, knowledge.

JEL Classification: J11, J43, J44, J60, M50

\section{Introduction}

Many current changes at business entities are associated with the transition to a new stage in the social development - the knowledge society. Experts are subject to constant changes and uncertainty. Some of their tasks lose their value and disappear, whereas the others are transformed and, somewhat, change. At the same time, there are the new tasks that require a higher level of professional activity transformation. The basis of intellectual capital of an enterprise is made up of people and their professional competencies, with a special place belonging to specialists in management activities. The instability of the environment, the breakdown of well-established industrial relations, changes in patterns of ownership and restructuring of enterprises require a revision of the developed stereotypes of managerial thinking and transition to new forms and methods of governance. Businesses need leaders whose relationships with organizations and employees should be based on the principles of professionalism, cooperation, mutual respect and clear understanding of mutual obligations.

The contemporary labour market, the main characteristics of which include flexibility, volatility, high innovation dynamics, introduces new requirements for employees. The study of the labour market creates the possibility of taking different measures for its

\footnotetext{
${ }^{1} \mathrm{PhD}$, Professor, Department of Management named after Prof. J.S. Zavadskiy, Heroyiv Oborony Street, 15 , 03040 Kyiv, Ukraine, e-mail: balanovskaya@nubip.edu.ua; https:orcid.org/0000-0001-6814-5888

$2 \mathrm{PhD}$, Faculty of Economic Sciences, Department of Economics and Organization of Enterprises, Nowoursynowska 166 Street, 02-787 Warsaw, e-mail: barbara wyrzykowska@sggw.pl;

https:orcid.org/0000-0002-7025-0799
} 
regulation and development - it will help the Ukrainian commodity producers to continue attracting qualified specialists at lower costs and getting a higher performance.

\section{Analysis of recent research and publications}

Problems of the labour market in general, and employment of the population, in particular, including the rural territories, together with the ways of their solution, attract the attention of various scientists and practitioners (Bolshaya,2012; Hryhorenko, 2018; Kovbasyuk, 2012 and others). Mushynski (2014), Pryimak (2012), Sukhy (2010), Wyrzykowska, Zaleśna (2017), Pabian (2011) and others devote their works to the problems connected with studying the requirements of the labour market for specialists. However, the analysis of the scientific papers has proved that many issues needs further clarification regarding the requirements of the labour market for specialists.

\section{Statement of the problem and methodology}

The purpose of the research is to determine the basic requirements of the contemporary labour market for specialists.

When doing research, the dialectical method of cognition was applied to collect, analyse, evaluate information and make conclusions, as well as the monographic method was used to structure the requirements for specialists.

\section{Results}

The professional activity of specialists of a modern enterprise requires special analysis of its structure and functions, the nature of tasks, organization of an appropriate system of training and self-training, development of professionally important qualities. At the same time, formation of professional competencies, both when training specialists at higher education institutions and creating the company's personnel development, is directly associated with market competition and the labour market requirements.

In Ukraine, according to the sample population survey (households) on economic activity, the average monthly number of economically active population aged 15-70 years in the dynamics decreases and in 2017 it included 17854,4 thousand people, 17 193,2 of which $(96,3 \%)$ were of working age. The highest level of economic activity was indicative for persons aged 35-49 years, and the lowest one was for young people aged 15-24 and persons aged 60-70. According to the State Statistics Service of Ukraine (Agriculture of Ukraine: The Statistical Year book for 2017, 2018), the number of the employed population aged $15-70$ years in Ukraine in dynamics also decreases, and in 2017 it amounted to 16156,4 thousand people (including 15495,9 thousand persons of working age), or $56,1 \%$ of the population of the corresponding age group and $90,5 \%$ of economically active population aged $15-70$ years. The level of employment of the working-age population was $64,5 \%$. The remaining 1698,0 thousand people, according to the International Labour Organization (ILO) methodology, were classified as unemployed. A major problem was the employment of young people aged 16-25 and people before retirement age (5-7 years before retirement). 
Out of the total number of the working population in agriculture, forestry and fishing, only $17,7 \%$ are employed (table 1 ).

Table1. Employment by type of economic activity ${ }^{1}$

\begin{tabular}{|c|c|c|c|c|c|c|c|c|c|c|c|}
\hline \multirow{2}{*}{$\begin{array}{c}\text { Type of economic } \\
\text { activity }\end{array}$} & \multicolumn{2}{|c|}{2013} & \multicolumn{2}{|c|}{2014} & \multicolumn{2}{|c|}{2015} & \multicolumn{2}{|c|}{2016} & \multicolumn{2}{|c|}{2017} & \multirow{2}{*}{$\begin{array}{l}2017 \text { in } \% \\
\text { until } \\
2013\end{array}$} \\
\hline & $\begin{array}{c}\text { thousand } \\
\text { people }\end{array}$ & $\%$ & $\begin{array}{l}\text { thousand } \\
\text { people }\end{array}$ & $\%$ & $\begin{array}{l}\text { thousand } \\
\text { people }\end{array}$ & $\%$ & $\begin{array}{l}\text { thousand } \\
\text { people }\end{array}$ & $\%$ & $\begin{array}{l}\text { thousand } \\
\text { people }\end{array}$ & $\%$ & \\
\hline $\begin{array}{l}\text { Agriculture, } \\
\text { forestry and fishing }\end{array}$ & 3577,5 & 17,5 & 3091,4 & 17,1 & 2870,6 & 17,5 & 2866,5 & 17,6 & 2860,7 & 17,7 & 80,0 \\
\hline Industry & 3274,8 & 16,0 & 2898,2 & 16,1 & 2573,9 & 15,7 & 2494,8 & 15,3 & 2440,6 & 15,1 & 74,5 \\
\hline Constructions & 888,8 & 4,4 & 746,4 & 4,1 & 642,1 & 3,9 & 644,5 & 4,0 & 644,3 & 4,0 & 72,5 \\
\hline $\begin{array}{l}\text { Wholesale and } \\
\text { retail trade; repair } \\
\text { of motor vehicles } \\
\text { and motorcycle }\end{array}$ & 4556,2 & 22,3 & 3965,7 & 21,9 & 3510,7 & 21,3 & 3516,2 & 21,6 & 3525,8 & 21,8 & 77,4 \\
\hline $\begin{array}{l}\text { Transportation and } \\
\text { storage, postal and } \\
\text { courier activities }\end{array}$ & 1221,2 & 6,0 & 1113,4 & 6,2 & 998,0 & 6,1 & 997,2 & 6,1 & 991,6 & 6,1 & 81,2 \\
\hline $\begin{array}{l}\text { Accommodation } \\
\text { and food service } \\
\text { activities }\end{array}$ & 357,8 & 1,8 & 309,1 & 1,7 & 277,3 & 1,7 & 276,7 & 1,7 & 276,3 & 1,7 & 77,2 \\
\hline $\begin{array}{l}\text { Other types of } \\
\text { economic activity }\end{array}$ & 6527,8 & 32,0 & 5949,1 & 32,9 & 5570,6 & 33,8 & 5481,0 & 33,7 & 5417,1 & 33,6 & 83,0 \\
\hline Total & 20404,1 & 100 & 18073,3 & 100 & 16443,2 & 100 & 16276,9 & 100 & 16156,4 & 100 & 79,2 \\
\hline
\end{tabular}

${ }^{1}$ Data for 2014 exclude the temporarily occupied territory of the Autonomous Republic of Crimea, the city of Sevastopol, from 2015 - also exclude a part of temporarily occupied territories in the Donetsk and Luhansk regions.

Source: calculated according to Agriculture of Ukraine: The Statistical Yearbook for 2017 (2018).

It should be emphasized that employed population (according to sample survey's data) is made up by the persons aged 15-70 who: worked during observed week at least one hour for hire, for reward in money or natural terms, individually (solely), for some persons or in the own (family) enterprise; worked free of charge on the enterprise, in business which is in private property of some household's member or in private farm in order to sell goods produced by means of this activity; temporary absentees at work, who formally had workplace, own enterprise (business), but did not work during the surveyed period for any reason. The distribution of the total employed by type of economic activity is made according to the Classification of Types of Economic Activity (State Classifier 009:2010) through a complex estimate based on integration of data from sample survey of households, the state statistical observations over enterprises and administrative reporting (Agriculture of Ukraine: The Statistical Yearbook for 2017, 2018).

In the structure of the employed population, regarding professional groups, the biggest part was formed by the people who were employed in the simplest professions $(18,9 \%)$, the professionals $(17,9 \%)$ and those who worked in the sphere of trade and services $(16,8 \%)$. Moreover, the smallest part was formed by the employed population that dealt with technical services $(3,0 \%)$ and qualified employees who worked in the agricultural sphere, forestry, fish-breeding and fishing $(0,9 \%)$ (Figure 1$)$. 


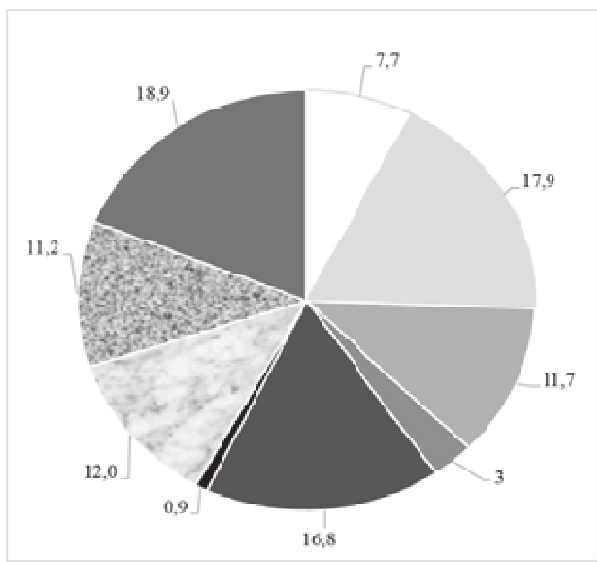

All employment population, $\%$



Rural employment population, \% legislators, seni or civil servants, managers

"professionals

" specialists

" technical staff

- workers in the sphere of trade and services

- skilled workers in rural and forestry, fish farming and fishing

skilled workers with tools

" workers on maintenance, operation and control over the work of technological equipment, assembly of equipment

" the simplest profession

Fig. 1. Structure of the employed population of Ukraine by professional groups

Source: calculated according to Agriculture of Ukraine: The Statistical Yearbook for 2017 (2018).

At the same time, the number of hired employees accounts for only $35,1 \%$ and includes those who are on the payroll and those who are not (contract workers and double jobholders) (Agriculture of Ukraine: The Statistical Yearbook for 2017, 2018) (table 1 and 2).

According to the State Statistics Service of Ukraine, the country's population is mostly occupied by small and medium-sized businesses. One can observe the same situation in the agrarian sector of the country, where the economic entities of various organizational and legal forms are successfully implemented (table 3 ). The prevailing organizational and legal form of farming in the countryside is the farms, the share of which in the overall structure made $74,9 \%$ in 2017.

Currently, the problem of the insufficient level of satisfaction of the employers' needs (regardless of their size, organization and legal form) in employees is topical, which is largely due to the lack of systematic information on relevant professions and jobs, a low level of interaction between employers and the educational sector. 
Table 2. Number of employees by type of economic activity ${ }^{1}$

\begin{tabular}{|c|c|c|c|c|c|c|c|c|c|c|c|}
\hline \multirow{2}{*}{$\begin{array}{l}\text { Type of economic } \\
\text { activity }\end{array}$} & \multicolumn{2}{|c|}{2013} & \multicolumn{2}{|c|}{2014} & \multicolumn{2}{|c|}{2015} & \multicolumn{2}{|c|}{2016} & \multicolumn{2}{|c|}{2017} & \multirow{2}{*}{$\begin{array}{l}2017 \text { in } \\
\% \text { until } \\
2013\end{array}$} \\
\hline & $\begin{array}{l}\text { thousand } \\
\text { people }\end{array}$ & $\%$ & $\begin{array}{l}\text { thousand } \\
\text { people }\end{array}$ & $\%$ & $\begin{array}{l}\text { thousand } \\
\text { people }\end{array}$ & $\%$ & $\begin{array}{l}\text { thousand } \\
\text { people }\end{array}$ & $\%$ & $\begin{array}{l}\text { thousand } \\
\text { people }\end{array}$ & $\%$ & \\
\hline $\begin{array}{l}\text { Agriculture, forestry } \\
\text { and fishing }\end{array}$ & 652,1 & 9,0 & 596,0 & 9,6 & 569,4 & 9,9 & 583,4 & 10,2 & 565,1 & 10,0 & 86,7 \\
\hline $\begin{array}{l}\text { including agriculture, } \\
\text { hunting and } \\
\text { respective services }\end{array}$ & 582,2 & 8,0 & 530,9 & 8,6 & 502,7 & 8,7 & 515,0 & 9,0 & 497,8 & 8,8 & 85,5 \\
\hline Industry & 2912,8 & 40,0 & 2419,3 & 39,1 & 2241,4 & 38,8 & 2168,4 & 38,0 & 2114,2 & 37,3 & 72,6 \\
\hline $\begin{array}{l}\text { including food, } \\
\text { beverages and } \\
\text { tobacco goods } \\
\text { production }\end{array}$ & 402,4 & 5,5 & 349,4 & 5,6 & 319,5 & 5,5 & 312,5 & 5,5 & 309,3 & 5,5 & 76,9 \\
\hline Constructions & 362,1 & 5,0 & 278,2 & 4,5 & 239,2 & 4,1 & 241,7 & 4,2 & 250,4 & 4,4 & 69,2 \\
\hline $\begin{array}{l}\text { Wholesale and retail } \\
\text { trade; repair of motor } \\
\text { vehicles and } \\
\text { motorcycles }\end{array}$ & 1129,3 & 15,5 & 993,4 & 16,0 & 899,9 & 15,6 & 912,8 & 16,0 & 962,9 & 17,0 & 85,3 \\
\hline $\begin{array}{l}\text { Transportation and } \\
\text { storage, postal and } \\
\text { courier activities }\end{array}$ & 907,9 & 12,5 & 758,8 & 12,2 & 772,7 & 13,4 & 762,2 & 13,3 & 757,3 & 13,3 & 83,4 \\
\hline $\begin{array}{l}\text { Accommodation and } \\
\text { food service } \\
\text { activities }\end{array}$ & 129,9 & 1,8 & 99,3 & 1,6 & 85,5 & 1,5 & 88,7 & 1,6 & 89,7 & 1,6 & 69,1 \\
\hline $\begin{array}{l}\text { Other types of } \\
\text { economic activity }\end{array}$ & 1191,5 & 16,2 & 1048,0 & 17,0 & 970,0 & 16,7 & 956,7 & 16,7 & 934,6 & 16,4 & 78,4 \\
\hline Total & 7285,6 & 100 & 6193,0 & 100 & 5778,1 & 100 & 5713,9 & 100 & 5674,2 & 100 & 77,9 \\
\hline
\end{tabular}

${ }^{1}$ Data for 2014 exclude the temporarily occupied territory of the Autonomous Republic of Crimea, the city of Sevastopol, from 2015 - also exclude a part of temporarily occupied territories in the Donetsk and Luhansk regions.

Source: calculated according to Agriculture of Ukraine: The Statistical Yearbook for 2017 (2018).

According to the survey conducted by the Union of the Ukrainian Entrepreneurs, two thirds of the polled representatives of small and medium-sized businesses intend to increase the number of employees in 2018, and one third of the respondents said that lack of qualified personnel is one of the main factors hindering business development. On the other hand, most Ukrainian companies, even claiming a shortage of personnel, practically do nothing to solve their problems. A significant part of employers do not want/cannot improve working conditions, motivate people, pay for their education (Hryhorenko, 2018).

At the same time, the changes in the structure of the demand for workers are due to the accelerated pace of change associated with the spread of advanced technologies throughout all the sectors of the economy. The modern labour market is dynamic, variable, flexible, global and depends crucially on the employer. These common features affect the requirements of the employee. They indicate that the profession is not an independent variable, which we get once and forever, being often without tuition fee. A professional career is not stable, it "interrupts" and, from year to year, more and more things depend on the ability of employees to adapt to the labour market and their readiness to perform 
functions under new conditions or in new fields of activity. The labour market forces employees to think about careers creatively and independently. Their awareness of own competence and competitiveness is of great importance. Passive expectations of specialists for favourable conditions at the labour market, or their expectation that others will take care of them, belong to the way of thinking that is unacceptable for those who desire to get a promising and a well-paid job (Mushynski, 2014).

Table 3. Dynamics of the number of operating economic entities for organizational and legal forms of management in agriculture of Ukraine, units

\begin{tabular}{|c|c|c|c|c|c|c|c|}
\hline $\begin{array}{l}\text { Organisational and } \\
\text { the legal forms of } \\
\text { business } \\
\text { management }\end{array}$ & 2013 & 2014 & $\begin{array}{l}\text { Years } \\
2015\end{array}$ & 2016 & 2017 & $\begin{array}{c}2017 \text { in } \% \text { to } \\
\text { the total }\end{array}$ & $\begin{array}{l}2017 \text { in \% } \\
\text { until } 2013\end{array}$ \\
\hline $\begin{array}{l}\text { Business } \\
\text { partnership }\end{array}$ & 8295 & 7750 & 7721 & 8700 & 6967 & 15,3 & 84,0 \\
\hline Private enterprises & 4153 & 3772 & 3627 & 3752 & 3215 & 7,1 & 77,4 \\
\hline Cooperatives & 810 & 674 & 596 & 738 & 448 & 1,0 & 55,3 \\
\hline Private farms & 40856 & 39428 & 32303 & 33682 & 34137 & 74,9 & 83,6 \\
\hline State enterprises & 278 & 228 & 241 & 222 & 199 & 0,4 & 71,6 \\
\hline $\begin{array}{l}\text { Enterprises of } \\
\text { other types of } \\
\text { business }\end{array}$ & 1466 & 691 & 891 & 603 & 592 & 1,3 & 40,4 \\
\hline Total & 55858 & 52543 & 45379 & 47697 & 45558 & 100,0 & 81,6 \\
\hline
\end{tabular}

${ }^{1}$ Data for 2014 exclude the temporarily occupied territory of the Autonomous Republic of Crimea, the city of Sevastopol, from 2015 - also exclude a part of temporarily occupied territories in the Donetsk and Luhansk regions

Source: calculated according to Agriculture of Ukraine: The Statistical Yearbook for 2017 (2018).

We fully agree with the opinion of the authors (Kovbasyuk et al., 2012) that nowadays in Ukraine there are unfavourable conditions for preservation and reproduction of human resources, human potential, which is a natural source of the formation of quality composition of employees in all the spheres of management. First of all, there are unfavourable socio-economic conditions; problems connected with ensuring the guaranteed constitutional right of citizens to work, free choice of profession and type of employment; a decrease of interest in the development of quality labour potential under the decline in the domestic production; aging population, poverty; non-demand for knowledge and intelligence when considering the current organizational and personnel model of public administration, lack of demand for new promising ways of applying knowledge and skills in various spheres, a low level of investment into education. Education, a social value for the modern society, does not possess former instrumental significance any longer. The positions are being lost regarding quality education, incentives for its acquisition and professional diversity. That is occurring even though the global trend of the beginning of the millennium involves the recognition that human development is a key resource for sustainable economic growth and competitiveness in the long run.

Talking about the training of managers, the improving quality of their education, ensuring its mobility, competitiveness in the labour market requires further improvement of the educational process organization at higher educational institutions. 
The results of the scientific research on the expectations of employers from specialists are presented in various domestic and foreign sources. In our opinion, the results of the research presented by Mushynski (2014) and conducted by Accenture and the Polish Society of Personnel Management are interesting and relevant for Ukraine as well. Thus, according to the report of the All-Polish Research, the most important factor is the competence of knowing foreign languages. Particular attention is paid to communicative skills and ability to work in a team. It is distinguishing that the special knowledge (hard skills) took the fourth place. The success of a candidate, who applies for a position, largely determines the motivation for further development, international internship and practice, as well as experience in a particular field and awareness of that. It turns out that all competencies that were asked by respondents are required by employers to a significant or high degree (the questions referred above are primarily "soft competencies": managerial skills, organization of their own work, autonomy, communication skills, teamwork skills, creativity). What follows from the above mentioned is that the narrow special education of the applicant for employment occupies the background. At the same time, there is an increase in the demand for quality and continuous vocational education, which has a clearly expressed intellectual, innovative and general cultural character.

It is also of great interest that Polish employers consider themselves to have to prepare each employee for work individually, because the educational system does not prepare them properly. In connection to that, the main values in the assessment of the employee contain: special education in accordance with the profession; experience; additional tolerances, confirmed by the relevant document; general competence, first of all, soft factors: attitude to work, desire to study, motivation, openness, cooperation in the group (Mushynski, 2014).

According to Sukhy (2010), the XXI century employers' demands include: actualization, expansion and deepening of knowledge and skills with orientation on the type of work performed and the needs of the employer's institution; getting a new or related profession, as well as expanding the scope of their skills; preparation for obtaining professional qualifications, professional or specialized ranks; mastering new technologies in view of organizational changes or new economic systems and occupying a position requiring special knowledge of occupational safety and health rules.

According to the results of the research, the requirements of employers (both Ukrainian and Polish) to future employees are different in relation to their professional experience. Some of them are looking for experienced professionals, focusing on seniority, practical training, professional work during training. Others require an unexperienced worker without previous work in another company, as an unexperienced candidate is more open to innovation than conservative, burdened by extensive experience. Each of the approaches has its supporters and opponents, but all employers agree with one statement: professional flexibility, which is understood as a complex of individual traits that facilitate quick adaptation to the specifics of work in a particular firm, is required in each particular field.

To manage a modern team of competent, skilled workers, the leader should be an erudite and highly educated person. Therefore, when it comes to the managerial position, in the opinion of employers, managers of the new generation should meet the modern requirements and should possess such professional knowledge and skills as critical thinking, promptly accept and implement high-performance management solutions; work with modern information technologies and means of communication; form their own opinion; generate ideas; provide a favourable psychological climate in the team; be able to quickly switch from one thought to another. The modern manager should have a high level 
of technical and economic knowledge, have a thorough knowledge of the art of personnel management and regulate relationships within the organization.

Successful professional activity of modern managers depends not only on their accumulated knowledge, skills and abilities, but also on personal qualities and abilities, flexibility and originality of thinking, the ability to form effective strategies for solving technical, economic and social problems. One of the undisputed positive qualities of managers' personalities are their leadership qualities. As it has been already noted in the previous studies (Balanovska, Gogulya, 2017), managers cannot be anyone but leaders as they should bring people together and inspire them to achieve a high goal. They will succeed in their work only if they can convince their subordinates of the ability to achieve such a level of performance that previously seemed unavailable to them. This leader's ability is closely linked to qualities such as the ability to form optimistic plans, to increase hopes for success, to explain the essence of innovation, to unite the team in crisis situations, and so on.

When it comes to managers, scientists also note personal qualities that impede success, among which are the emotional imbalance, laziness, passivity, vulnerability to the imposition of another will, excessive zeal and punctuality. In particular, Stevens (1996) identified a number of personal qualities of character that interfere with human harmony and ability to live and act successfully. He called them "dragons" and showed that personality factors can be both useful and harmful to humans. Among them, Stevens J. referred to: arrogance, which can be based on the fear of insecurity, negative assessments, or overestimation of significance; impatience that manifests itself in the fear of losing time. People infected with such fear are constantly in the state of stress, trying to get maximum in a short period of time and dreaming about the future, not being able to live in the present (here and now). External manifestations of such people's behaviour will include mild excitement, rudeness, irritability, inflexibility and hastiness in decisions; internal anxiety, tendency to panic, irritability and capriciousness; greed that finds it explicit manifestation in egoism, apostasy, propensity for gender and envy for someone else's wealth, whereas it implicitly manifests in the sense of deprivation and insecurity. It is impossible to get rid of these traits of character completely, but they can be "tamed" and used for the benefit of themselves and people.

It should be noted that besides the actual personal qualities and possession of a set of specific knowledge, skills and abilities in the sphere in which the manager works, the ability to think logically, that is, the ability to reason, draw parallels, analyse the information that comes in and make the right conclusions is also an important factor. It is logical thinking that allows making proper decisions. The ability is important for all employees whose work involves making logical decisions based on comprehensive information. The development of thinking is of great importance throughout the world. In most highly developed countries, there are national programmes for the development of children's intellectual and creative abilities. Productive thinking is formed when solving non-standard tasks, searching for new approaches to standard ones. An important issue is the development of thinking in future leaders as a powerful tool for the qualitative acquisition of knowledge and skills and their creative use in practice (Balanovska, Gogulya, 2017). The problem of thinking development is especially relevant in modern conditions, since time is putting forward the new requirements for specialists in almost all branches of human activity. There is a need for the development of thinking as a powerful tool for the qualitative acquisition of knowledge and skills, together with their creative use in practice in order to acquire new knowledge and make reasonable decisions. 


\section{Conclusions}

The findings of the research give grounds to draw a conclusion that the number of the employed population in Ukraine is decreasing in dynamics. Small and medium-sized enterprises of various organizational and legal forms employ the largest part of the population. Nowadays in Ukraine there is a huge problem with employment of young people aged 16-25 years. At the same time, one of the obstacles to business development is the insufficient number of highly skilled professionals in the labour market. The contemporary labour market needs to improve the complex of competencies in the process of preparing future competitive workforce for different sectors. The ability to quickly adapt to new conditions, stress tolerance, communication skills, and the desire for lifelong learning are among the main requirements of employers for professionals. Specialists who possess non-standard thinking, creative abilities and potential to realize themselves in their professional activity are valued. In addition, in today's world, the generally accepted requirements for specialists with higher education are tolerance, discipline, punctuality, self-confidence, team-working ability, adequate assessment of production situations, and the availability of practical skills for working with innovative technologies.

The requirements of employers for the competence of specialists determine the innovative changes in the educational process. The current issue is to minimize the gap between higher education, academic science and practical activity. It is important that graduates of higher education institutions have all the necessary knowledge, know how to use professional terminology, have practical skills in the relevant field, as well as the possibility of continuous improvement of their own professional characteristics. The rapid change in the conditions of production necessitates the continuous improvement and updating of knowledge, skills and abilities of employees. In this regard, at all stages of the educational process, students should form their aspirations for lifelong learning.

The professional competence of any specialist, including the manager, is supposed to be formed by systematic upgrading of qualifications, creative activity, the ability to productively meet the growing labor market requirements. Moreover, modern business requires the emergence of a new generation of professional managers of different managerial levels that are able to fully accumulate the entire potential of the enterprise and focus it on implementing the strategy of the enterprise in accordance with the realities of the business environment.

\section{References}

Agriculture of Ukraine: The Statistical Yearbook for 2017. (2018). Accountable for issue O.M. Prokopenko. Kyiv: State Statistics Service of Ukraine, 245 p. Available from: http://www.ukrstat.gov.ua/druk/publicat/ kat_u/2018/zb/09/zb_sg2017_pdf.pdf.

Balanovska, T., Gogulya, O. (2017). Features of the formation of managers of the agrarian sphere in the context of modern labor market needs. Global and national problems of the economy. 2017 №9. Available from: http://global-national.in.ua/issue-19-2017.

Bolshaya, O. (2012). The problem of youth employment in the labor market of Ukraine. Ekonomika i Region, 2 , 114-118.

Economic Code of Ukraine: Law of Ukraine dated January 16, 2003. No. 436-IV (as amended on November 6 2017). Available from: http://zakon2.rada.gov.ua/laws/show/436-15. 
Hryhorenko, Yu. (2018). Labor market in 2018: Ukrainians want to receive more than employers can give. Available from: https://ua.112.ua/statji/rynok-pratsi-v-2018-rotsi-ukraintsi-khochut-otrymuvaty-bilshe-nizhmozhut-daty-robotodavtsi-431936.html.

Kovbasyuk, Yu., Vashchenko, K., Surmin, Yu. (2012). State staff policy in Ukraine: state, problems and prospects of development: a scientific report. Kyiv: NAPA, 72 p. Available from: http://academy.gov.ua/ NMKD/ library nadu/Monografiy/08295121-aecf-499c-a114-9a08b5d8841c.pdf.

Mushynski, A. (2014). Requirements of modern labour-market to specialists' professional and personality qualities in the context of their continuous education in Poland. The Scientific Issues of Ternopil Volodymyr Hnatiuk National Pedagogical University. Series: Pedagogy, 3. 141-146.

Pabian, A. (2011). Sustainable personel - pracownicy przedsiębiorstwa przyszłości (Sustainable Personnel Employees of Future Enterprise). Zarzadzanie Zasobami Ludzkimi, 5, 13-14.

Pryimak, V. (2012). Model's Professional Competencies a Modern Manager. Bulletin of Taras Shevchenko National University of Kyiv. Economics, 137, 49-53.

Stevens, J. (1996). Tame your dragons. How to turn your faults into virtues. St. Petersburg, 480 p. Available from: http://secret-of-success.sulfurzona.com/files/books/Stivens_-_Priruchi_svoih_drakonov.pdf.

Sukhy, S. (2010). Education of adult employees and the unemployed. Warsaw: Difin SA, 212 p.

Wyrzykowska, B., Zaleśna, A. (2017). Kompetencje menedżerów w zrównoważonej organizacji. (Competences of managers for sustainable organization). Studia i Prace WNEiZ US, 48(2), 373-382.

\section{For citation:}

Balanovska T., Wyrzykowska B. (2018). The Requirements of the Contemporary Labour Market for Professionals. Problems of World Agriculture, 18(4), 92-101; DOI: 10.22630/PRS.2018.18.4.100 